common in any particular group of occupations. A probably identical condition has been described on the Continent as occurring in pigeon fanciers, who use grain held in their mouths to force-feed the young birds, the so-called pigeon crammers' disease.

Cause.-As indicated, $A$. fumigatus is normally nonpathogenic and it is not known why an allergic response should occur in a minority of individuals exposed to it. Presumably, however, this is a further example of an abnormal and genetically determined reaction to a foreign protein.

\section{An Early Sign of Lead Poisoning}

\section{BY}

\section{W. G. PEARCE and W. A. REYNARD}

From the Oxford Eye Hospital and Medical Department, Pressed Steel Co. Ltd., Oxford

(RECEIVED FOR PUBLICATION JANUARY 29, 1964)

In the New England Journal of Medicine of October 10, 1963 an article by N. Sonkin described Retinal Stippling -a New Physical Sign in the Early Diagnosis of Lead Poisoning. In this paper Sonkin described stippling around the optic disc which consisted of glistening grey discrete spots that he considered to be lead pigment. This was noted to be present in eight men who had been mixing various lead compounds for the manufacture of wire insulation. These deposits were present in all of the men even though the urinary lead values in some of the men were not significant. Four months after removal from exposure to the lead compounds this physical sign had disappeared. Sonkin considered that this sign may be present before there is laboratory evidence of lead toxicity.

In many industrial processes involving a lead hazard, the industrial medical officer has need of every possible sign that might assist him in drawing that most difficult line which separates lead absorption from lead intoxication. All men on a lead process absorb small quantities of lead: what is needed is a reliable sign which will indicate excessive absorption or early lead poisoning and therefore the need to remove the worker from the environment containing lead.

It was therefore felt that this new retinal sign should be investigated in a group of workmen known to be exposed to lead and, in varying degree, to be absorbing lead.

In a factory manufacturing motor car bodies, approximately 800 men are working in an atmosphere containing finely divided (some less than 5 microns) solder dust. Every two months they receive a clinical examination, haemoglobin estimation, enumeration of punctate basophilia of the erythrocytes, and a qualitative examination of the urine for coproporphyrin. Each day a batch of men is examined, and these are selected at random from all parts of the factory according only to the dictates of sustained production.

It was decided to examine the fundus of each man presenting in the daily batches until 100 had been examined, the other tests being continued collaterally. In fact 102 men had their fundi examined by an ophthalmologist using a Keeler Specialist Ophthalmoscope in a dark room.

Of the 102 men examined, 11 showed evidence of lead absorption to a degree that caused them to be removed from the process. The findings in these men are shown in the Table.

TABLE

\begin{tabular}{|c|c|c|c|}
\hline Haemoglobin $(\%)$ & $\begin{array}{c}\text { Qualitative } \\
\text { Coproporphyrin* }\end{array}$ & $\begin{array}{c}\text { Punctates } \\
\text { Per Million } \\
\text { R.B.C. } \dagger\end{array}$ & $\begin{array}{l}\text { Period on } \\
\text { Lead } \\
\text { Work }\end{array}$ \\
\hline $\begin{array}{r}103 \\
119 \\
100 \\
106 \\
89 \\
103 \\
93 \\
108 \\
96 \\
109 \\
101\end{array}$ & $\begin{array}{l}++++ \\
++++ \\
++++ \\
++++ \\
++++ \\
++++ \\
++++ \\
++++ \\
++++ \\
++++ \\
++++\end{array}$ & $\begin{array}{r}2,100 \\
6,800 \\
2,700 \\
7,300 \\
4,200 \\
6,300 \\
3,000 \\
4,500 \\
4,700 \\
2,700 \\
11,800\end{array}$ & $\begin{array}{r}15 \mathrm{yr} 9 \mathrm{mth} \\
3 \mathrm{yr} 7 \mathrm{mth} \\
3 \mathrm{yr} 5 \mathrm{mth} \\
9 \mathrm{yr} 4 \mathrm{mth} \\
16 \mathrm{yr} 6 \mathrm{mth} \\
13 \mathrm{yr} 3 \mathrm{mth} \\
2 \mathrm{yr} \\
9 \mathrm{yr} \\
15 \mathrm{yr} \\
17 \mathrm{yr} 7 \mathrm{mth} \\
5 \mathrm{yr}\end{array}$ \\
\hline $\begin{array}{r}++ \\
+++ \\
++++\end{array}$ & $\begin{array}{l}\text { ximately equal to } \\
\text {," } \\
\text { ", }\end{array}$ & $\begin{array}{l}0 \mu \mathrm{g} . / \mathrm{day} \\
0 \mu \mathrm{g} . / \mathrm{day} \\
0-1,500 \mu \mathrm{g} . / \mathrm{d} \\
0-3,000 \mu \mathrm{g} . / \mathrm{d}\end{array}$ & \\
\hline
\end{tabular}

Not one of the 102 men examined, including the 11 with signs of excessive lead absorption, showed the discrete grey deposits around the optic disc described by Sonkin.

Having failed to find retinal stippling in men known to be absorbing lead to a degree which tests at present in use cause us to grade as excessive, we cannot recommend that examination of the fundus has any place in the medical control of workmen exposed to lead absorption. 